(c) The Author(s) 2021

p-ISSN: 2722-8894; e-ISSN: 2722-8886

DOI: $10.47043 /$ ijipth.v2i2.22

https://aafki-afti.org/ijipth

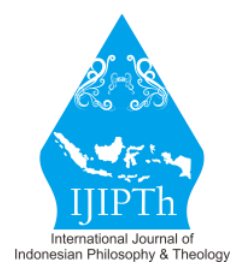

\title{
From Theocentric to Theopraxis: Renegotiating Theology in the Context of the Plurality of Traditions in Asia
}

\author{
Clarence Devadass \\ The Catholic Research Centre, Malaysia \\ Email: csdass@gmail.com
}

\begin{abstract}
The Church in Asia received first the gift of the Christian faith through missionary activity, starting with the Apostles and then later through the colonial expansion. For a long time, the good news has been spread through various means - conversion, persuasion and sometimes compulsion, especially when most of Asia was colonized by the 'Christian West'. The post-colonial era (in Asia) has seen a revival in the Christian faith and many other Asian traditions and religions. Does this now call for a reimagining of what it means to be a 'Church in Asia"? The Church in Asia has to "redefine" its mission in the light of the changing socio-economic-political landscape. There is a need also to look at the merging theology that brings 'uniqueness' to the Church in Asia. Here I propose to look at emerging theology as put forward by the Federation of Asian Bishops' Conferences $(\mathrm{FABC})$ and discover the changing landscape of doing theology from theocentric towards the direction of being theopraxis.
\end{abstract}

Keywords: Asian theology, Theocentric, Theopraxis, Plurality of Traditions, FABC

\begin{abstract}
Abstrak: Gereja meperoleh anugerah iman lewat para misionaris yang bersamaan dengan ekspansi colonial. Kabar Gembira Injil menyebar melalui pertobatan dan upaya-upaya untuk meyakinkan orang Asia memeluk iman Kristiani. Era Poskolonial kini berhembus pula di tanah Asia. Era ini meminta pula umat Kristen untuk bertanya, seperti apakah "Gereja di Asia"? Gereja Asia dipanggil untuk meredefinisikan misi dan kehadirannya di tengahtengah landscape persoalan ekonomi, politik, social yang serius. Redefinisi Gereja di Asia memungkinan upaya teologis yang secara unik harus dijalankan di Gereja Asia. Dalam studi ini saya mengajukan simakan ulang atas teologi yang berkembang di Asia sebagaimana ditangkap pula oleh Konferensi Uskup-Uskup Asia dan berusaha menemukan "landscape" teologis yang terus berkembang dari teosentris ke arah teopraxis.
\end{abstract}

Kata Kunci: Teologi Asia, Teosentris, Teopraxis, tradisi plural, FABC

\section{Introduction}

The purpose of my study as a respondent effort immediately after the paper of Prof Wilfred (2020) is to offer another perspective with regard to Doing Theology in Contemporary Asia. It is not my intent to contest or debate this comprehensive paper, but to offer another angle so as to complement this topic that we are discussing.

The great Christian philosopher and theologian, St Anselm of Canterbury (1033-1109 AD), had as his motto fides quaerens intellectum (faith seeking understanding), and it is likely that this maintained his interest and motivation in the pursuit of both philosophy and theology. His contributions to philosophical theology could be said to be groundbreaking even though Augustine of Hippo (354-430 AD) was among the first to incorporate philosophical ideas into Christian theology. Much of his philosophical and theological reasoning was influenced by Greek philosophy. For centuries, theology, rather than philosophy, had been the domain of seminaries, for those seeking to enter religious life. It was more likely that, during the period of enlightenment, theology became a study in its own right. Prior to this period, there was little distinction between spirituality and theology. The writings of the Early 
Church Fathers would probably bear testimony to this fact. For them, the goal of trying to understand God through the study of theology was to be able to have a spiritual relationship with God. Before theology became a specialized science, especially in institutes of higher learning, theology was intended to improve life - per scientiam crescat amor. There was very little that would distinguish one "science" from the other - theology and spirituality had the same goal.

At its inception, the development of theology in the context of spiritual theology was made possible by the fusion of divine revelation with the religious experience of the human person: "Spiritual theology is that part of theology that, proceeding from the truths of divine revelation and the religious experience of individual persons, defines the nature of the supernatural life, formulates directives for its growth and development, and explains the process by which advance from the beginning of the spiritual life to its full perfection" (Aumann, 2006). For this reason, fides quaerens intellectum was intended to make the precepts of the faith as comprehensible as possible. It is surely not possible for the human person to understand the whole of divine revelation, but the process is to narrow the gap between faith and reason for the purpose of a religious experience. In the words of Pope John Paul II, "faith and reason are like two wings on which the human spirit rises to the contemplation of truth; and God has placed in the human heart a desire to know the truth- in a word, to know himself- so that, by knowing and loving God, men and women may also come to the fullness of truth about themselves" (John Paul, 1998).

Not only does the word "reason" refer to intellectual reasoning, but also implicit in it are moral and cultural reasoning. Theology is not just an abstract intellectual activity but it must have moral and social repercussions, for "it is my prayer that your love for one another may grow more and more with the knowledge and complete understanding" (Phil 1:9). If it were to remain a purely "speculative science", then it would cease to consider human reality that shapes human life. Void of this reality then, theology remains abstract and finds its place once again only in institutions of higher learning and only accessible to the "elite".

Faith and reason cannot be the only basis for doing (studying) theology today. If theology is to make any sense in the current situation, then it must also take into consideration human experience as one of the axes for doing theology. This has been the locus of doing theology, especially in Asia, given the richness of its diversity and the plurality of the Asian people. The purpose here is to explore how theological praxis has become integral, especially in Asia, in relation to the direction of the Federation of Asian Bishops' Conferences (FABC). I propose to look at the key characteristics that have become somewhat normative in doing theology, especially in the FABC in the last three decades, and to try to elucidate the way in which theology is evolving from being theocentric towards theopraxis, from being purely God-centered to a God experience.

\section{The Asian Reality}

Christianity, like many other religious traditions, finds its roots in Asia. The birth of Christ and the life of the early Church were centered in Asia before its expansion westward. It is estimated that thirteen per cent of the world's Christian population is located in Asia. Proportionately, this would seem to be a significant number, and studies show that Christianity is on the rise in Asia. However, even though Christianity is spread across Asia, apart from the Philippines and Timor-Leste, it is a minority religion in all other countries in Asia (excluding Oceania). Although Christianity was born in Asia, it was only during the colonial expansion that the Christian faith expanded and took root in many countries 
throughout Asia. Therefore, Christianity has had a long history and tradition in the life of the Asian peoples.

In recent times, the Church in Asia has been shaped by various circumstances that have led to a redefining of ecclesiology, which has prompted a new way of engaging with theological reflections. From its inception, the FABC has had at its very heart the desire to reflect on the Asian way of "being Church". It is clear that "the FABC has proceeded on the basis that the Asian continent, with its teeming masses and their rich diversity and plurality of religions, cultures, and philosophical worldviews, requires a distinctively Asian ecclesiology, a 'new way of being church' that is at home in such diversity and pluralism" (Tan, 2005). The diversity and plurality of Asia define theological reflections. It has therefore become imperative to understand the changing circumstances that are shaping Asia, because this has direct consequences for theological reflection. The following are some key characteristics (not exhaustive) of the "new" Asian realities that are shaping Asian theology and contributing to Asian reflection.

a) Plurality of traditions: Asia is the most populous continent among all other continents and therefore does not project a single face. It would be erroneous to think that it has only one tradition, and the diversity of traditions are often reflected in its cultures, languages and also religious traditions. All this plurality demonstrates that reflections on, and experience of, God are equally diverse. Sometimes the reality is that these diversities are not just restricted to national boundaries; even within the confines of a particular country, there can be great diversity. For example, it is believed that India has over two thousand ethic groups and that every major religion is present. The plurality of cultures and traditions are further amplified by the impact that migration has had on the world; the world in itself is becoming pluri-cultural in more ways than one.

b) Poverty: In Asia, poverty is a major problem. It is a fact that many peoples of Asia are struggling with poverty, which is evident in the increase in urban and rural poverty. Based on the daily minimum (< USD1.51 per day), the Asian Development Bank estimates that one-third of Asia's population would be considered "poor". The cause of poverty in Asia cannot be reduced to one primary course but to a variety of reasons. Social and structural deficiencies could be considered to be among the causes of poverty in Asia, for example, excessive population growth, inequitable distribution of wealth and a lack of education. The language of the "preferential option for the poor" has been the mainstay of the Catholic Social teachings since the mid 1970s. Here, the option for the poor refers especially to a trend throughout the Bible, where a noticeable preference is given to poor and powerless individuals living on the margins of society. Since a significant part of the face of Asia remains poor and some even disadvantaged, theological reflection cannot exclude this aspect of life in Asia. Another dimension of this "preferential option for the poor" was also evident when Pope John Paul II used the term, and elaborated on the concept in his encyclical Centesimus Annus, where he expanded the use of the "option for the poor" to include spiritual and cultural, as well as material, poverty: "The Church's love for the poor, which is essential for her and a part of her constant tradition, impels her to give attention to a world in which poverty is threatening to assume massive proportions in spite of technological and economic progress" (John Paul, 1991).

c) Social structures: Closely connected to the problem of poverty, unjust social structures have contributed significantly to the life of the Asian peoples. Within these structures lie the problems of corruption, gender bias, child labour, exploitation - human and ecological - and threats to human life. In many parts of Asia, people live under the threat of war and armed conflict, and these conflicts 
are between not just countries but also ethnic groups. These realities shape the face of Asia today and we cannot remain oblivious to the fact that theology has a place in the call for honesty, accountability, equality and justice. These have become the concerns in Asia, and theology must also therefore play a role in reflection on these issues that are close to the heart of the Asian peoples.

d) Demographic changes: Asia is one of the largest contributors to the phenomenon of labour migration. One of the primary impacts of such migration are the consequences for the primary social institution - the family. In the sending countries, when parents leave their families to improve their quality of life, the psychological development of the children is surely impacted, and there has been a tremendous impact for the family as a locus for any religious experience. On the other hand, in the receiving countries, these new demographic changes bring with them cultural diversity. Places that have been mono-cultural for centuries are now faced with this new plurality. This phenomenon in Asia has had a social, political and economic impact in many parts of Asia. Social structures, political engagement and economic stresses have impacted countries that both send and receive migrants. For this reason, the basic structures of society have been reimagined to accommodate these changes.

e) Dialogue and harmony: Theology in Asia cannot be done in isolation from other religious traditions, since all major religious traditions are found across Asia. There is a sense of the sacred in most Asian traditions. The fact that Christians live among the peoples of many other religions is itself an indication that Christian theology cannot exist only to serve itself. It is not uncommon for families in Asia to be interreligious and intercultural in their composition. This mixture in society, and especially in the basic institution of the family, calls for a "new reading" of theology, perhaps quite different from that of the Christian West. The value of harmony and integration among the peoples of Asia calls for an openness to dialogue and respect that must be seen in doing theology. What Asia seeks is that "unity, peace and harmony are to be realised in diversity... since it represents richness and strength" (Federation of Asian Bishops' Conferences, 1975). Therefore, key to doing theology in Asia are also inclusivity and respect for other cultures and traditions.

f) Secularization: Rapid advancements in the area of media have infiltrated many parts of Asia and one of the outcomes of this development is secularization. Secularization primarily refers to the historical procedure whereby religion loses its cultural and social importance in the lives of people. There was a time when religious values were embedded in social institutions, but experiences in Asia have led to the creation of a non-religious institutional framework. In the past, religion occupied a place of importance in the lives of many people and also institutions such as schools and hospitals and in the everyday governance of society. However, this has rapidly changed in the last three decades and secularization continues to have an impact in many parts of Asia. The direct consequences of secularization can be seen, in particular, in the change of value systems - cultural and traditional values are being replaced with new ideological influences that emanate mainly from the West.

g) Ecological degradation: The focus on creation in worship is not something alien to the JudeoChristian tradition and to Asian traditions. The two creation accounts that are found in the book of Genesis attest that creation is indeed central to the Christian vision of the world and God's relationship to it. The creation accounts in some ways present not only the relational dimension the cosmic reality but also points to a divine-cosmic liturgy that already existed in the Judeo-Christian liturgy. With the dawn of the industrialised civilization and the rapid growth of age of technology 
especially here in Asia where many of the countries are in need of "development", the connection between creation and human society becomes more reduced and objectified. The dwindling of this dynamic relationship also causes not only the distancing of the divine-cosmic relationship but for theology to rediscover the interconnectedness and the dynamic relationship shared by God-SelfOther-Cosmos.

h) Religious radicalisation / extremism: The process by which an individual, or group comes to adopt increasingly extreme political, social, or religious ideals and aspirations that reject or undermine the status quo or contemporary ideas and expressions of the nation are realities that Asia is experiencing more than before. A recent study carried out by UNESCO states that there is a rising trend in religious extremism (in South Asia) that is causing instability in the region. The report states that deteriorating socio-economic conditions, government policies and outside interference in all South Asian countries have been the primary factors responsible for the rise of extremism in the region. The rise of Hindu extremism in India, Islam in Pakistan, Indonesia and Malaysia, Buddhism in Myanmar are some of the examples in Asia. Perhaps more relevant to us in Indonesia and Malaysia, the Council on Foreign Relations published last year on how "the rise of Islamism in both these countries could have severe consequences for the two states' societies, political systems and overall stability".

In the light of all these changing realties, how does on 'do theology' especially where there are challenges both within and without the Church? As mentioned earlier, doing theology in a pluralistic society cannot exclude these overwhelming realities that shape and perhaps more today than before, define Asia.

\section{Trends in Theology}

Any student embarking on a route to studying theology, for ministerial purposes or otherwise, would certainly be introduced to Bernard Lonergan's (1972) Method in Theology. This work could be considered his most important work, since it provides a framework for doing theology. In short, the interplay of the heart and mind in Lonergan's Method can be considered his contribution to theological inquiry. The view of Lonergan is that "unless we attend seriously to what actually happens in minds and hearts, we tend to resort to metaphors that describe what 'doing' theology involves. In contrast to metaphorical descriptions, an analysis of actual events of our minds and hearts leads to explanations that can be tested in experience" (Dunne, 2017). The emergence of Lonergan's framework for doing theology was instrumental, not just in the study of theology but also in other fields. However, his work could be said to have revolutionized the approach to theology in many institutions of higher learning.

Although the work of Lonergan redefined the way that theology is approached as a methodological study, it cannot be said that we have not had similar approaches in the development of theology in the Western Church. The Early Church Fathers were prominent theologians who can be attributed with having set the framework for developing Christian theology. In the Western Church, they were people such as Ambrose (c. 340-397 AD), Jerome (c. 347-420 AD), Augustine (c. 354-430 AD) and Saint Gregory the Great (c. 540-604 AD), while in the Eastern Church they included Basil the Great (c. 329379 AD), Athanasius (c. 296-373 AD), Gregory of Nazianzus (c. 329-389 AD) and John Chrysostom (c. 347-407 AD). Among the above, Augustine of Hippo is considered to be one of the most important figures in the development of Western Christianity. His integration of Greek 
philosophical traditions and the Judeo-Christian religious and scriptural traditions set the tone for the future of the development of Christian theology in the West.

There have been various phases in the development of Christian theology in the different periods. From the patristic period through to medieval Christian theology and scholasticism, and then the Renaissance and Reformation toward postmodern theology, each period has contributed, in its own way, to the development of Christian theology. However, it is not my intention to trace the entire development of Christian theology through the ages. It is sufficient to note that the study of theology has gone through a process of evolution in terms of its methodological approach, both in the East and West, and this has contributed to the development of Christian theology.

It we trace the starting position of theology in more recent times, possibly in the last thirty years, we discover three broad positions that define the direction that theologizing has taken. The first takes an exclusivist position. This position in theology holds that Jesus Christ is the sole Savior of the world and that the Christian faith is the only way to salvation. The second position is that of inclusivism. The underlying thought is that the other religions possess "some truths" but are not considered to be valid paths for salvation: "Inclusivism attempts to integrate non-Christian religions into Christian reflection" (Ih-ren Mong, 2015). The third position in theology is pluralism, which takes the position that there are truths in all religions and therefore each religion needs the other to complement it. In other words, there are "many" paths that lead towards the same goal - salvation. Whatever position a person takes in doing theology, all have their advantages and disadvantages and contribute in some way to the study and development of theology.

\section{The "Approach" of the FABC}

One may ask, "Is there a distinct approach that the FABC utilizes in doing theology in Asia?" The answer is "yes" and "no". There is a certain framework that is in operation, which is relatively diverse when applied to the different parts of Asia. This framework from which theology is reflected is perhaps the contribution of the FABC to the Church in Asia and to the world. The "approach" utilized by the FABC provides four key points for the purpose of doing theology in Asia.

At the First Plenary Assembly of the FABC in 1974, the fundamental question posed to participants was, "How can a numerically insignificant community such as the Christian one in Asia carry out its missionary task among peoples of ancient civilizations and spiritual traditions?" This was the basic question to which the first FABC (First Plenary Assembly of the Federation of Asian Bishops' Conferences), held in Taipei in 1974, tried to give an answer.

Since its inception the FABC has had at its heart the desire to read theology in relation to the Asian experience. The spirit behind the FABC's direction for doing theological reflection in a particular way takes its cue from the Second Vatican Council:

Vatican II spoke of expressing the faith in the languages and cultures of various peoples, but there is an even more fundamental aspect that must be recognized. We are Christians because we have experienced that Christ lives in us and we in him. This is an experience of individuals in Asia and of different peoples or Churches in Asia. This experience may have come through a concrete Jewish and European history, but those in Asia sharing this experience and Asian. The seed of the Word has fallen into the rich soil of Asia. It penetrates that soil and produces fruits that may be different from the results of other branches. To theologize in Asia, to give reasons, to explain and to be critically conscious means to be a Christian is not an exercise of translating experiences of past generations (be they Western or Eastern) into some modern Asian jargon, but rather an attempt to express from the depth of the Asian psyche the ineffable experience of living faith in Jesus Christ. 
It is the result of a genuine incarnation of the mystery of Christ in the flesh and blood of Asian peoples (Federation of Asian Bishops' Conferences, 2000).

In other words, the desire of the founding fathers of the FABC, in terms of doing theology, was from the beginning to move from purely speculative theology to theology from the ground leading upward. Theology is not just an abstract intellectual activity; it must have social implications, and for that to happen theology must also be inspired by the social implications. It is apparent then that "the starting point of the FABC's contextual theological methodology is a commitment and service to life which goes beyond a mere personal, existential, ontological or metaphysical quest for a systematic way of doing theology" (Tan, 2003). Some key characteristics of doing theology in Asia can be described as follows.

\section{The Asian locus for theology}

The tradition from which Western theology has evolved is the Greek philosophical ideas that were assimilated into Western theology. When the first missionaries set foot in Asia, this brand of theology was also incorporated into the life and experience of the Asian peoples. In quoting the Korean theologian Bong Rin Ro, Johan Tangelder captures what has taken place in terms of doing theology in Asia: "Theological ideas are created on the Continent (Europe), corrected in Great Britain, corrupted in America and crammed in to Asia" (Tangelder, 2017).

This has perhaps caused a great division in the study of theology in Asia because theology for Asian people should resonate with the lived experience to even begin to make any sense. The theological reflection of Asia views human experience as the basis for bringing theology to resonate with human life. Although human experience can be relatively subjective, it is this subjectiveness that makes theological reflection more nuanced with ordinary life. The way in which theology has developed in Asia in recent years is based on the premise that human experience (Christian experience) is indeed prior to theology because "[t]heology, understood as systematic and critical investigation, is in itself incapable of producing Christian experience by its own resources... theology is born of Christian [human] experience" (Scola, 1996).

As much as theology has its own rationality, human experience also has its rationality, and these do not need to be in opposition. There are times when the subjectivity of human experience is viewed with suspicion. The fear of introducing human experience into theology resides in the question of whether theology loses its rational objectivity when subjective human experience is introduced. Nevertheless, the Asian character in doing theology is about "taking into account contextual realities as resources of theology” (Federation of Asian Bishops' Conferences, 2000).

\section{Theology as engagement with life}

Theology is considered an interdisciplinary inquiry. The interdisciplinary nature of theology itself provides a hermeneutical approach. By hermeneutical I mean interpreting practice and theory by understanding not just texts and data but also culture and conventions (Reynhout, 2013). The theological approach in the FABC has been an attempt to engage with life. In some studies, this is known as "contextual theology" or "situational theology" - it is a way in which the Church tries to adapt or apply its teachings to the various life and cultural environments of its people. It is also here that words such as "inculturation" or "enculturation" have been applied. However, through the ages there has been a constant tension, possibly even fear, that the truths of the faith, when accommodated to culture, can instead become compromised. 
For Asian people, the celebration of life's milestones form the core of their spiritual experience, for example, birth, initiation (coming of age), marriage and death. These moments are celebrated culturally in many communities in Asia. The theology of the FABC also seeks to be in dialogue with these key moments in a person's life and to provide a theological reflection that resonates with life. Therefore, inculturation seems to be a way of trying to enrich theological reflections, especially in the field of liturgy, for the spiritual essence of the Asian peoples can now become part of the Christian identity, which has sometimes been considered to be something "imported" from the West. It is because of the importance of these special moments in their lives that theology should engage such realities.

\section{Dialogical Paradigm}

The Christian community in Asia, the most populous continent in the world, represents a tiny minority. Since everyday life is lived among peoples of other faith and traditions, it is necessary that respect and understanding be imbedded in theological reflection. For this purpose, the FABC paradigm of a triple dialogue must form the foundations for doing theology and life. This has been the thrust of the FABC: "For the Church in Asia to truly discover its own identity it must continually engage in a 'three-fold dialogue' with the peoples (especially the poor), the cultures, and the religions of Asia. This programmatic vision of a 'triple dialogue' has guided the FABC for over three decades. One can assert that as the FABC pursues its vision and practice of dialogue, it forges bonds of unity and builds community in the Asian context" (Kroeger, 2011).

The "three-fold dialogue" considers the realities of Asia and its challenges to be an integral part of being Church in this part of the world. First, the reality of poverty in Asia is an overwhelming issue that any theological reflection cannot afford to overlook. The reality of the poor (as discussed earlier) is crucial to making theology relevant and rooted in one of the primary realities of Asia. Secondly, seeing that Asia is a potpourri of cultures, theological reflection must be factored into this reality. Culture would include the way that people have lived for centuries, and there is a certain value system that has been built into human relationships, which includes relationships with God, self, society and nature. The Asian people, no matter what religion they may profess, hold in high regard some of these cultural values that have been practiced for a very long time. Thirdly, since Asia is the seedbed of many of the major religions of the world, Christian theology must be done in a way that encourages harmony and respect, despite the uniqueness of each religion and tradition. In this way, therefore, the social-culturalreligious realities of Asia can only assist in the FABC's efforts at theologizing.

\section{Understanding “other theologies”}

Living among other religious traditions and cultures, it is important to understand the teachings and views of the other. In the theological reflections of the FABC, there is always a consideration of what the other religious traditions and cultures believe on the same topic. Asia is richly ingrained with a variety of resources. Among the resources are not only the organized religious traditions but also the indigenous spiritualties that enrich the life of the peoples of Asia.

The spirit behind trying to understand the "other theologies" comes from the exhortation expressed by the Second Vatican Council: "Religions, however, that are bound up with an advanced culture have struggled to answer the same questions by means of more refined concepts and a more developed language... The Church, therefore, exhorts her sons, that through dialogue and collaboration with the followers of other religions, carried out with prudence and love and in witness to the Christian faith and 
life, they recognize, preserve and promote the good things, spiritual and moral, as well as the sociocultural values found among these men... The Catholic Church rejects nothing that is true and holy in these religions" (Second Vatican Council, 1965). It is therefore in this spirit that the FABC seeks to find common ground that promotes greater harmony, respect and commonality in working together.

From the outset, one of the thrusts of the FABC has been to collaborate with the other religions in Asia. At the Asian Bishops' meeting in 1970, one of the resolutions clearly states: "We [the Bishops] pledge ourselves to an open, sincere and continuing dialogue with our brothers and sisters of other great religions of Asia, that we may learn from one another how to enrich ourselves spiritually and how to work more effectively together on our common task of total human development". This resolution has been an integral part of the theologizing process in the FABC because the goal is to find paths of convergence rather than divergence.

\section{Theology as "experimental"}

The study and approach to theology are very much in their infancy in Asia when considered against the development of theology in the West. Although the great Fathers of the Church from the East were prolific in their development of theology, it still embraced a Western model of doing theology - the discursive and empirical method. This does not mean that the theology that is being reflected in the FABC lacks empirical knowledge, but, together with it, there is also an insistence on "experimental knowledge", which is seen in the light of the pastoral implications and applications of the theology that have been considered.

Since the region of Asia is so vast and diverse, the pastoral implications and applications can be equally vast and diverse. There is no "one model fits all" solution that applies to all peoples across Asia. In this sense, many of the applications can be considered "experimental" because of the uniqueness of the Asian situation. Sound theology also has to be practical. Void of the pastoral or practical dimension, theology can remain a classroom exercise with no engagement with life. Every region throughout Asia is unique in itself and therefore the Asian population remains diverse.

\section{Conclusion}

In putting forth his arguments for the existence of God, St Thomas Aquinas begins with that which is observable and then leads to God. The five proofs of the existence of God are derived from the common observation, and, from them, he is then able to demonstrate that God exists. In the same way, the Asian approach, as seen in the works of the FABC, begins with the observable, seeing how God is at work in the Asian reality. If in the past theology has employed deductive methods of reasoning, one can conclude that the FABC's approach urges more toward the inductive methods of reasoning. In social research methods, deductive reasoning is sometimes informally called a "top-down" approach, while inductive reasoning begins with the observable experience. In the past, in relation to theology, it was considered reasoning based on theoretical deduction (theocentric), but the "Asian approach" to reasoning is based on empirical observation (theopraxis).

The difference seems to be in the starting point of doing theology. The "Western" approach begins with the logic a priori, while the Eastern method takes on logic a posteriori. However, both approaches to reasoning have a common objective, that is, faith being the ultimate goal. The inductive (empirical) method of reasoning is not only peculiar to the Asian context. The other continents, namely Africa and 
Latin America, have employed similar methods in doing theology. However, the contexts in these places are quite different and distinct from Asia.

Key to doing theology, as put forth in the FABC, lies in its starting point - it is not the description of God but the experience of God in the lives of the people. The difference lies herein:

[I]n contrast to the traditional theological discursive orientation of classicist theological methods which are invariably metaphysical in orientation, [classicist theological methods] have traditionally focusses upon wisdom (sapientia) and rational knowledge (scientia), and are often detached from the daily living experiences of its target audience, the contextual theological methodology of FABC is primarily pastoral on orientation, seeking both to be shaped by, as well as to shape daily life experiences in the multireligious, multiethnic, multilingual and pluricultural Asian Sitz-im-Leben... the starting point of the FABC's contextual theological methodology is not the universal precepts of lex aeterna and lex naturalis, or abstract metaphysical principles pertaining to God, Revelation and the Christian Gospel, or even conciliar, papal or doctrinal pronouncements, but rather the life experiences of the Asian peoples (Tan, 2003).

In keeping the four bases for doing theology in Asia, namely, the Asian reality, Asian resources, theological reflection and some practical implications, "the Church [in Asia] could have an opportunity at last to present the beauty of her faith in Jesus Christ in language attuned to the times (Francis, 2017)."

\section{References}

Asian Bishops' Meeting. (1970): Resolutions of the Asian Bishops Meeting,” no. 12.

Aumann, Jordan. (2006). Spiritual Theology. London: Continuum.

Dunne, Ted. (2017). "Method in Theology: A summary of the views of Bernard Lonergan, taken from his book, Method in Theology", accessed September 17, 2017, https://www.lonerganresource.com/pdf/articles/Dunne-Method_in_Theology_-

_A_Summary.pdf

Federation of Asian Bishops' Conference. (1975). Final Document of the Bishops' Institute for Social Action II. Hong Kong: FABC Papers.

Federation of Asian Bishops' Conferences. (2000). Methodology: Asian Christian Theology - Doing Theology in Asia Today. Hong Kong: FABC Papers.

Francis, Pope. (2017). "Address to the participants in the meetings promoted by the Pontifical Council for Promoting the New Evangelization," 11 October, https://w2.vatican.va/content/francesco/en/speeches/2017/october/documents/papafrancesco_20171011_convegno-nuova-evangelizzazione.html

Ih-Ren Mong, Ambrose. (2015). Dialogue Derailed: Joseph Ratzinger's War Against Pluralist Theology. Oregon: Pickwick Publications.

John Paul II, Pope. (1998). Fides et ratio: On the relationship between faith and reason. Vatican City: Libreria Editrice Vaticana.

John Paul II, Pope. (1991). Encyclical Letter Centesimus Annus. Vatican City: Libreria Editrice Vaticana.

Kim, Sebastian C.H. (2008). Christian Theology in Asia. Cambridge, UK: Cambridge University Press. Kroeger, James. (2011). “An 'Asian' Dialogue Decalogue. Principles of Interreligious Dialogue from Asia's Bishops," a talk given during the Theological Forum "Theological Views on Religions and Cultures" held July 21-23, at the Loyola School of Theology.

Lonergan, Bernard. (1972). Method in Theology. New York: Herder \& Herder. 
Reynhout, Kenneth A. (2013). Interdisciplinary Interpretation: Paul Ricoeur and the Hermeneutics of Theology and Science, (Langham: Lexington Books, 2013), 11, https://ebookcentral.proquest.com/lib/cam/detail.action?docID=1207421.

Lovin, Robin W., and Joshua Mauldin. 2017. Theology as Interdisciplinary Inquiry: Learning with and from the Natural and Human Sciences. Michigan: Eerdmans Publishing Company.

Mong, Ambrose. (2015). Dialogue Derailed. Oregon: Pickwick.

Reynhout, Kenneth A. (2015). Interdisciplinary Interpretation: Paul Ricoeur and the Hermeneutics of Theology and Science. Langham: Lexington Books.

Scola, Angelo. (1996). "Christian Experience and Theology," Communio: International Catholic Review (Summer), http://www.ewtn.com/library/theology/extheo.htm.

Second Vatican Council. (1965). Nostra aetate: Declaration on the Relation of the Church with Non-

Christian Religions (Vatican City), 2.

http://www.vatican.va/archive/hist_councils/ii_vatican_council/documents/vat-

ii_decl_19651028_nostra-aetate_en.html

Tan, Jonathan Yun-Ka. (2005). "A New Way of Being Church in Asia: The Federation of Asian Bishops' Conferences (FABC) at the Service of Life in Pluralistic Asia." Missiology: An International Review Vol XXXIII, no. 1 (January): 73.

Tan, Jonathan Yun-ka. (2003). "Theologizing at the Service of Life: The Contextual Theological Methodology of the Federation of Asian Bishops' Conferences (FABC)", FABC Papers No. 108. Hong Kong: FABC, October.

Tangelder, Johan D. (2017). "Theological Trends in Asia", accessed October 20, 2017, http://www.reformedreflections.ca/articles/th-theological-trends-asia.html.

Wolfteich, Claire E., and Annemie Dillen. (2016). Catholic Approaches in Practical Theology: International and Interdisciplinary Perspective. Lueven: Peeters.

Wilfred, Felix. (2020). Asian Theological Ferment (For Doing Theology in Contemporary Indonesia: Interdisciplinary Perspectives). International Journal of Indonesian Philosophy and Theology, 1(2), 73-90. https://doi.org/10.47043/ijipth.v1i2 